\title{
Endemic risks: influenza pandemics, public health, and making self-reliant Indian citizens ${ }^{\dagger}$
}

\author{
Kavita Sivaramakrishnan \\ Center for the History and Ethics of Public Health, Sociomedical Sciences, Mailman School of Public Health, Columbia \\ University, 722 West 168th Street, 9th Floor, New York, NY 10032, USA \\ Corresponding author. E-mail: ks2890@cumc.columbia.edu
}

\begin{abstract}
This article focuses on the politics of epidemics, health and development in the years between two pandemics of influenza in India, the so-called 'Asian' flu (1957) and the 'Hong Kong' flu (1968). I explore how public health and risk-focused cosmologies were constructed about urban life, and anchored in economic priorities about development planning, industrial productivity, and self-reliance in a modernizing Indian nation. How were pandemics 'seen' and identified among urban populations that were already suffering from endemic risks? Were they viewed as a continuum of local, natural hazards or through wider geopolitical insecurities? The influenza crises were characterized by incapacitation and absenteeism from work rather than high mortality rates in Indian cities, causing worries about industrial plans. The Indian state intervened minimally, and articulated ideas and rhetoric about individual responsibility and 'cooperative citizenship' that set the stage for later manifestations of neoliberalism.
\end{abstract}

Keywords: cities; development; endemic; India; influenza; pandemic; risk

\section{Introduction}

Writing to his daughter, Indira, from a prison cell in 1933, Jawaharal Nehru instructed her about the immense power and promise of science and technology - its potential for reaching new heights of reason and cooperation, and reinforcing the structures of culture and civilization. He warned that the power of this science, however, could also be destructive. One of the scenarios he etched was that of whole cities affected by diseases or infections through the use of biological weapons - pathogens released deliberately among civilian populations that led to epidemics and deaths. ${ }^{1}$

A few decades later, in independent India, as a Nehruvian vision of industrial, economic modernization fuelled by science and technology deepened, and a planned economy was put in place, the possibility of biological warfare, disease attacks, and other threats were now viewed as necessary risks that had to be taken as being numbered among the many downsides of industrial modernization and urbanization. Industrialization and modern scientific research involved calculated

\footnotetext{
${ }^{\dagger} \mathrm{I}$ am grateful for the valuable research support and inputs provided by our graduate students Valentina Parisi and Purbasha Das at Columbia University, and also Aishani Roy at Presidency College, Kolkata. I would also like to thank my colleagues Connie Nathanson, Partha Chatterjee, and Heidi Tworek for discussing various aspects of this project with me.

${ }^{1} J a w a h a r l a l$ Nehru, 'Letter to his daughter from his jail cell, Dehradun, July 14, 1933', in Jawaharlal Nehru on Science and Society: A Collection of His Writings and Speeches, ed. Baldev Singh (New Delhi: Nehru Memorial Museum and Library, 1988), 14-15. For work on Nehruvian science, postcolonial technoscience, and contemporary Indian scientists and their politics, see David Arnold, 'Nehruvian Science and Postcolonial India', Isis 104, no. 2 (June 2013): 360-70; Robert S. Anderson, Building Scientific Institutions in India: Saha and Bhabha (Montreal: McGill University Centre for Developing Studies, 1975); Warwick Anderson, 'Postcolonial Technoscience', Social Studies of Science 32 (2002): 643-58.
} 
risks, stemming from India's opening itself up to science and civilization, including their destructive aspects, among which were the side effects of medical and scientific technologies. Public figures therefore articulated ideas and thoughts that rationalized the risks that India was taking based on a critical calculus of development. ${ }^{2}$ It was seen as imperative for the Indian nation to modernize by consolidating science and technology and developing international ties and industrial growth, even if these efforts could expose the country to vulnerabilities of both old and newly proliferating disease perils.

At the annual conference of the Indian Public Health Association of 1960, held in Bombay, M. S. Kannamwar, minister of health of Bombay State, voiced and developed these ideas further. He observed that India's objective of shortening its path from underdevelopment to development required it to rapidly adopt modern steps while facing serious new handicaps created by the age of nuclear fission, and fresh hazards to health. ${ }^{3}$ The minister spoke with the voice of recent experience: in 1957-58 an influenza pandemic had swept through Bombay city and most of the world, bringing the agenda of eradicating communicable diseases to the forefront. When the influenza arrived, members of the public health and scientific community in India and abroad termed it the 'Asian' flu from China, which had arrived via Singapore. A less common view, from a few authors in public health journals and in local newspapers, speculated that the flu virus had been triggered by a disturbance or imbalance caused by a radioactive explosion, leading to a mutation in pathogens and their diffusion. ${ }^{4}$

These pandemic risks and threats in the late 1950s and throughout the 1960s were reported by contemporaries and public health experts through the lens of Cold War geopolitics, insecurities about the arms race, and fears regarding deliberately weaponized pathogens and resultant pandemics 'stalking' Western societies and their vulnerable populations. US experts, in particular, saw their country as being susceptible to 'attacks' both on the coasts and inland, with the rapid spread of pandemics such as influenza. ${ }^{5}$ Its experts acknowledged that the country had a tremendous stake in international health. Other countries, such as the UK, in reports following the 1957 influenza outbreak, adopted a similar vocabulary of the pandemic representing an 'invasion' that originated in the Far East. ${ }^{6}$

The aim of this article is to focus on the events and responses during and in the years following the 1957-58 influenza pandemic in India. I shall explore how pandemics such as this one, and the concerns and ideas that they generated, created spaces and debates at a local level, where nationalistic priorities and wider geopolitical anxieties intersected and overlapped with enduring, daily risks and uncertainties experienced by urban publics. How did endemic health risks and local epidemics intersect with the arrival of 'new' pandemics and how were these unplanned health risks and responses relating to pandemic influenza (which arrived and spread across India in

\footnotetext{
${ }^{2}$ Sunil Amrith, 'Political Culture of Health in India: A Historical Perspective', Economic and Political Weekly 42, no. 2 (2007): 114-21; Sugata Bose, 'Instruments and Idioms of Colonial and National Development: The Indian Experience in Comparative Perspective', in International Development and the Social Sciences: Essays in the History and Politics of Knowledge, ed. F. Cooper and R. Packard (Berkeley and Los Angeles: University of California Press, 1997), 45-63; Jean Dreze and Amartya Sen, India: Development and Participation (New Delhi: Oxford University Press, 2002); Benjamin Zachariah, Developing India: An Intellectual and Social History, 1930-50 (New Delhi: Oxford University Press, 2005), 30-43; P. C. Mahalanobis, 'The Approach of Operational Research to Planning in India', Sankhyā: The Indian Journal of Statistics 16, no. 1/2 (December 1955): 3-130; P. C. Mahalanobis, 'A Look at India's Forward Planning: Interview with P. C. Mahalanobis', Ekistics 12, no. 73 (November 1961): 353-5.

${ }^{3}$ Inaugural Address by Shri M. S. Kannamwar, Minister of Health, Bombay State, Indian Journal of Public Health 4 (1960): 22 .

${ }^{4}$ Amiyonath Mitra, 'Influenza', Jugantar Patrika 20, no. 274 (20 June 1957): 11. I am grateful to Aishani Roy for searches and assistance in translation. See also discussions later in the article.

${ }^{5}$ Hubert H. Humphrey, in Committee on Government Operations, United States Senate, The United States and the World Health Organization: Teamwork for Mankind's Well-Being (Washington, DC: U.S. Government, 1959), 55-6.

${ }^{6}$ Ministry of Health (UK), The Influenza Epidemic in England and Wales 1957-1958 (London: HMSO, 1960), 5-7 and 54, retrieved from https://archive.org/details/op1266941-1001.
} 
1957-58 in epidemic form) situated in the context of development, economic 'planning', and industrial work?

The 'Asian' influenza pandemic was not a dramatic and deadly scourge. But, as it seeped gradually across Indian cities, and when cases peaked through the summer of 1957, with families and communities laid up with fever, pneumonia, and exhaustion, it created growing anxieties among the public. ${ }^{7}$ It therefore offers an opportunity to understand how a collective sense of risk was linked to uncertainty spreading across cities. Many scholars have written about the Indian state's prioritization of development planning programmes, and have stressed that this was a commitment that leading members of the Indian nationalist, political elite had articulated even in the years before Indian independence, in groups such as the National Planning Committee, when a vision to escape economic and social backwardness was articulated. ${ }^{8}$ This required a planned economy that eventually promised an elevated standard of living through 'coordinated action', and this development also required capitalist discipline and socialism to cooperate. Such a vision of planning and its promise implicitly necessitated a certain self-discipline and regulation in the nation as a whole but also in its workforce. ${ }^{9}$

As this vision and rhetoric deepened through the 1950 and 1960s, the centrality of planning and appraising productivity implied that national policies in disease control and health required investment in 'vertical' singular, disease programmes for a few, prioritized diseases - among them malaria, and tuberculosis. ${ }^{10}$ Within a few years, there were already reports of vector resistance to insecticides such as DDT, and this was a setback to plague control and malaria eradication. ${ }^{11}$ Meanwhile, a lack of local health infrastructure made it difficult to consolidate and preserve the progress made in infectious disease containment.

In 1950, the World Health Organization (WHO) had set up a World Influenza Centre with collaborating states and experts, and this centre played a key role in tracking the pandemic in May 1957 and later, after it reached Singapore and moved through South Asia, and, in June, arrived in the United Kingdom and the United States. ${ }^{12}$ Prominent US politicians such as the Minnesota senator Hubert Humphrey argued that the WHO influenza pandemic network enabled its experts and politicians to receive worldwide warning of the spread of disease. Although the 1957-58 influenza pandemic was not virulent and did not cause large-scale deaths, notice of its spread ensured the preparation of a vaccine in advance. In the US, politicians increasingly perceived this pandemic as representing a case of 'Communist China' and its failure to alert global officials of virus isolation in a timely manner. ${ }^{13}$

\footnotetext{
${ }^{7}$ Government of India, Annual Report of the Directorate General of Health Services, 1957 (New Delhi: Ministry of Health, Government of India, 1958), 191, table 11. States with the greatest number of cases included Bombay $(1,282,459$ reported cases, 1,408 reported deaths), Madras (610, 262 reported cases, 74 reported deaths), and Mysore (416,275 reported cases, 70 reported deaths). Andhra Pradesh, Kerala, Madhya Pradesh, Uttar Pradesh, and West Bengal all reported cases in the mid to high 200,000s.

${ }^{8}$ Bose, 'Instruments and Idioms'; David Ludden, 'India's Development Regime' in Colonialism and Culture, ed. Nicholas Dirks (Ann Arbor: University of Michigan Press, 1992); Partha Chatterjee, 'Development Planning and the Indian State', in The State and Development Planning in India, ed. T. J. Byres (New Delhi: Oxford University Press, 1993); Zachariah, Developing India.

${ }^{9}$ Zachariah, Developing India, 243-53.

${ }^{10}$ Amrith, 'Political Culture of Health in India'

${ }^{11}$ See S. C. Seal, 'Epidemiological Studies of Plague in India: The Present Position', Bulletin of the World Health Organization 23 (1969): 289-90.

${ }^{12}$ See Henry van Zile Hyde, World Health Organization, Progress and Plans (Washington, DC: U.S. Government Printing Office, 1948); for the UK, see Ministry of Health (UK), Influenza Epidemic in England and Wales.

${ }^{13}$ Humphrey, in Committee on Government Operations, The United States and the World Health Organization, 55-6: 'Through the World Health Organization the United States Secures the benefit of a worldwide disease warning system at a very small cost to the American taxpayer.' I explore these events in more detail in a separate article on the politics of preparedness in the US and international health.
} 
Indian scientists took a different approach. While being linked with international networks of research on influenza in Europe and the US, they were more interested in mapping new and mutated viruses within the Indian landscape than tracing them to Asia, even in years of fraught geopolitical tensions with China. ${ }^{14}$ Additionally, by the 1970s, there were newer anxieties emerging that replaced the concerns relating to overcoming backwardness and 'underdevelopment' in the 1950s. Fears of collaboration in public health and agriculture with the West could also lead to distrust about surveillance and biologically manufactured threats. What this makes clear is that historians need to focus on and compare the stakes that pandemic preparedness held for different nations, and how these defined their relationships indirectly with international partners.

India's postcolonial predicament and its pandemic response were linked. The crisis was often downplayed. Instead of summoning a large-scale public health machinery and coordinated response at a national level, many public figures interpreted the influenza pandemic as a series of localized, 'epidemic' outbreaks along with other 'endemic' conditions, an approach undoubtedly facilitated by the fact that India's health administration empowered states with the powers to enact epidemic and public health acts. Public health bodies responded by trying to control key urban public spaces and medical services, and largely retreated behind an on-and-off rhetoric of citizen-led vigilance and civic cooperation.

Policy-makers instead discussed the pandemic-related 'crisis' within the context of the goals and limits of modernization, rather than a pathogenic siege or attack. This 'crisis' encompassed two aspects. The first involved worries about work, absenteeism in the labour force, and urban disease landscapes, stressing key moral and social requirements, such as cooperation and labour productivity, that could cement India's national future. The second aspect, an emerging concern by the late 1960s, related to the intersections between medical research, development, and modernization, which always carried anxieties about biological warfare, and India's growing vulnerabilities as its scientific cooperation and intellectual investment in these projects deepened. My research in this article focuses primarily on the first aspect. By examining an unexplored archive of news reports across Indian cities, Hindi and Bengali periodicals, urban epidemiological surveys, and political debates in India and in the West, it is possible to piece together this complex conjuncture, and to investigate the interactions between epidemic outbreaks and anxieties about capital, labour efficiency, and productivity. My focus is therefore to trace the shifting ideas and sensibilities about risks relating to self-discipline, suffering, and regulation that were articulated by experts, politicians, and the public. ${ }^{15}$

\section{Endemic risk in a contagious city}

In 1964, one of India's leading epidemiologists, S. C. Seal, reflected on the relationships between different categories of infectious disease outbreaks that had occurred recently in his home city, Calcutta. ${ }^{16}$ After discussing how professional epidemiologists formally classified these disease categories, Seal turned to arguing that these classifications and disease notifications had to be flexibly applied and adjusted within the contextual challenges of public health in Calcutta. He stated that an epidemic was an attack involving pathogens when new cases of infection broke out, such as malaria or cholera in New York, London, or Paris - or Calcutta reporting new types of dengue or

\footnotetext{
${ }^{14}$ Old and new viruses and their surveillance were identified within a shifting pathogen landscape in India. See H. I. Jhala, 'Progress of Virology in India', in Y. M. Freitas and F. Fernandes, eds., Global Impacts of Applied Microbiology: Proceedings [of the] Third International Conference (Bombay: University of Bombay, 1971), 313-18.

${ }^{15}$ Daniel Wickberg, 'What is the History of Sensibilities? On Cultural Histories, Old and New', American Historical Review 112, no. 3 (2007): 664-5, 661-84; Peter N. Stearns and Susan Matt, Doing Emotions History (Evanston: University of Illinois Press, 2014); Peter N. Stearns and Carol Z. Stearns, 'Emotionology: Clarifying the History of Emotions and Emotional Standards', American Historical Review 90, no. 4 (1985): 813-36.

${ }^{16}$ S. C. Seal, 'The Problem of Epidemics in Calcutta', Adhi-Vyadhi 1, no. 8 (1965): 1-4. Another relevant article is Seal, 'Epidemiological Studies of Plague in India'. This perspective regarding endemic disease and epidemics in Calcutta was echoed by N. C. Chatterjee, Welcome Address, Indian Journal of Public Health, 10, no. 2 (1965): 42-3.
} 
influenza. An endemic outbreak was one where the 'majority of a population have already suffered an earlier case of similar infection knowingly or unknowingly', such as cholera and smallpox. A 'pandemic' was one that spread quickly from one region to another 'or takes over an entire nation', such as the influenza pandemic of $1957-58 .{ }^{17} \mathrm{He}$ argued, however, that these distinctions remained nebulous on the ground. The city of Calcutta, in his view, suffered from 'epidemics [that] arise from an endemic state. The sources of these infectious diseases remain dormant perennially, but in one- or two-year intervals they develop into an epidemic - like cholera, smallpox, diphtheria, chicken-pox, measles, etc. Some diseases circle the city year round - like typhoid, paratyphoid, tuberculosis, diarrhoea, and various respiratory diseases, influenza, bronchitis, pneumonia, etc.'18

Studying three key features in Calcutta - 'the human body, the pathogens and the environment responsible for transmission of infections' - he observed that Calcutta's epidemics and constant outbreaks were related to the presence of multiple kinds of pathogens that could 'lead to a relative equilibrium state, and the effort to eradicate one kind of infection then leads to the strengthening of the other, leading to a new epidemic', such as control of malaria leading to viral fevers and so on. ${ }^{19}$ Seal traced an overlap of social or environmental factors - accidents, unemployment, crowds, beggars, housing problems - impinging on the key features behind this endemicity of epidemics 'in and around the city'. In addition, Calcutta was exposed to newer influences, being the hub of 'intra and international connections', and to a massive influx of industrial workers, creating tremendous population density. These deprivations interacted with poor public health facilities such as deficient water supply, unattended garbage, adulterated foods, unlicensed stables, and 'air pollution from gasoline smoke coming out from factories, industry establishments and motorcars' ${ }^{20}$

Textbooks neatly differentiated threats and types of outbreaks that Seal vividly described as overlapping and jostling in Calcutta. This conveyed an understanding of a spatial mobility and density of pathogens not only in a biological sense but also embedded in unordered, uncontrolled bodies and constitutions that were trapped in a compromised ecology and environment. His ideas offer an interesting backdrop for analysing the onset of the influenza pandemic of 1957-58 in Calcutta and its diffusion to other cities.

Seal's reference to the presence of multiple pathogens that were constantly locked in battle and causing infectious diseases was derived from theories advanced by contemporaries such as the Australian epidemiologist Frank MacFarlane Burnet, who had written about the persistence of infectious diseases that were linked to complex ecological factors, and were unstable because 'man lives in an environment constantly being changed by his own activities'. ${ }^{21}$ Seal drew on these connections in his study of Calcutta to understand the city's rapidly changing urban landscape. ${ }^{22}$ There are echoes, too, in his writings of Charles Rosenberg's later discussion of nineteenth-century responses to cholera in the United States. Rosenberg's essay describes how contemporaries entering cities experienced a 'sensory overload' represented by the perils of industrialized city life, such as population density, putrefaction, and the endemicity of diseases, which he terms 'the pathogenic consequences of progress'. Living in urban centres was viewed as generating cultural and moral anxieties about 'progress and pathology'. ${ }^{23}$

\footnotetext{
${ }^{17}$ Seal, 'Problem of Epidemics in Calcutta'.

${ }^{18}$ Ibid., 1.

${ }^{19}$ Ibid.

${ }^{20}$ Ibid., 3-4.

${ }^{21}$ F. Macfarlane Burnet, Natural History of Infectious Disease, 2nd ed. (Cambridge: Cambridge University Press, 1953), 24. I am grateful to Valentina Parisi for discussion of Burnet's work.

${ }^{22}$ Seal quoted Burnet in one of his later articles referring to the aetiology of the influence pandemic in 1957-58: S. C. Seal, 'Health Hazards from Atomic Radiation', Indian Journal of Public Health, 1, no. 1 (1957): 45-7. Burnet's work is also discussed in Warwick Anderson, 'Natural Histories of Infectious Diseases: Ecological Vision in Twentieth-Century Biomedical Sciences', Osiris 19 (2004): 39-61.

${ }^{23}$ Charles E. Rosenberg, 'Pathologies of Progress: The Idea of Civilization as Risk', Bulletin of the History of Medicine 72 , no. 4 (1998): 714-30.
} 
However, industrialization and progress had no potential moral parable in contemporary health debates in the 1950s in India. Instead, the path to breaking this infectious disease 'equilibrium' was portrayed as industrial development, technology, and modernization, to overcome a recent history of colonization and backwardness, and to catch up with the West. Seal saw public health experts and medical interventions as playing a vital role, 'as the basic structure of all India cities was the same', but his recommendations, surprisingly, did not include a stronger and more interventionist state-led welfare presence. In his writings, and (as we shall see) in the debates around contemporary health crises caused by the influenza pandemics, the state and its public health apparatus hovered on the shadowy fringes of this catalogue of endemic crises, without addressing the 'hidden' or fundamental causes of these outbreaks. Unlike policy-makers during the 1957-58 epidemic, Seal's essay urged his readers to understand these endemic ecologies in the case of Calcutta.

Seal wrote some years after the influenza pandemic. News reports and debates from the time of its rapid spread in urban centres bring out how experts and medical administrators understood its implications. Seal's colleagues at the All India Institute of Hygiene and Public Health (IIHPH) had initiated an epidemiological investigation into the influenza 'epidemic' in Calcutta. They surmised that it had arrived in the city in the early part of June and persisted until June 1958. It arrived, they noted, 'after an interval of nearly 40 years and like many of the previous ones, originated in the Far East, in continental China ... infection was soon carried to the adjacent British colony of Hong Kong and then to Singapore ... From this port, infection was rapidly carried by human travelers to India and other countries in South East Asia. ${ }^{24}$

In and around Calcutta, where it arrived from Madras, the pandemic lasted for about two months, having already badly affected Bombay and Madras. ${ }^{25}$ The public health department and municipal corporation of Calcutta reported in mid June that close to 50,000 had been affected by influenza, most having contracted the disease again after recovering from it. It was hard to initially identify the new influenza outbreak. At its peak in June-July 1957, excess mortality from influenza and related causes (such as bronchitis and pneumonia) rose, with an excess of 1,488 registered deaths compared to the corresponding weeks in 1956. Morbidity was highest among the inhabitants of bustees (slums and low-income settlements) and among children; it was also high among people over forty-five years of age, with huge incapacitation among adults. ${ }^{26}$ The IIHPH survey, conducted in 870 randomly chosen parts of north and south Calcutta, revealed that about $80 \%$ of families had been attacked by the disease; there were 1,496,000 cases and 1,055 deaths in the survey area. Most of the worst-affected areas were in the most overcrowded parts of the city, in the bustees, where homes had few rooms, overcrowding was rife, and the worst living conditions prevailed. ${ }^{27}$

Contemporary newspapers and health reports reported anxieties about what was increasingly a defining concern about the influenza pandemic: its rapid spread and expansion to industrial areas and townships (such as the coalfields of Dharia) and its tendency to incapacitate a productive labour force. However, even with the news of its rapid spread across Indian cities, reporting on the pandemic in Hindi and Bengali newspapers and in most of the English press involved characterizing the disease as an 'epidemic', reinforcing its local, immediate nature. Health and

\footnotetext{
${ }^{24}$ L. M. Bhattacharji, A. K. Banerji, B. B. Chatterji, B. Halder, and M. N. Lahiri, 'Epidemiology of 1957 Influenza Epidemic in Calcutta', Indian Journal of Medical Research 47, no. 1 (1959): 108. The authors were researchers at the IIHPH, India's first school of public health, founded with support from the Rockefeller Foundation and the Government of India.

${ }^{25}$ There are two views regarding the arrival of the influenza pandemic in India. Government of India, Annual Report of the Directorate General of Health Services, 1957, stated that the outbreak started simultaneously in Madras and Bombay. I. G. K. Menon, deputy director of the Pasteur Institute of Southern India (designated the Government of India Influenza Centre) in Coonoor, wrote that it originated in Madras, where it had been carried by passengers from Singapore: see I. J. K. Menon, 'The 1957 Pandemic of Influenza in India', Bulletin of the World Health Organization 20 (1959): 194-224.

${ }^{26}$ 'Bengal Government Appeal: Extension of Vacation', Times of India, 11 July 1957.

${ }^{27}$ Bhattacharji et al., 'Epidemiology of 1957 Influenza Epidemic in Calcutta'.
} 
disease updates continued to barely distinguish the 'new' epidemic from other concurrent outbreaks. Reports in the cities of Nagpur and Lucknow covered influenza and growing cases of encephalitis together, speaking of the growing threat of viral diseases; and cholera deaths in Orissa jostled with reports of influenza. ${ }^{28}$ In a typical report of 1957 in the Bengali-language Jugantar Patrika, the health news for Calcutta was summed up as: 'Two have died due to influenza in Kolkata. Almost a dozen have been admitted in various hospitals around the city. Eleven more suspected to have contracted cholera and one person afflicted with chickenpox have been admitted to hospitals on this day. ${ }^{29}$

\section{Public reactions and scientific responses to the outbreak}

As influenza cases spread and rose in numbers, questions about the diseases 'arrival' and origin began to dominate public debate, and these prompted lengthy and intense exchanges among government and opposition leaders in the Indian Parliament, with the latter questioning the government's vigilance and deterrent actions at the borders and ports. One of the prominent origin stories was that, in May 1957, influenza was carried by travellers from Singapore aboard a well-known liner, the SS Rajula. ${ }^{30}$ Legislators in Parliament asked why efforts to quarantine the ship offshore near Madras and to inspect its sick passengers had failed, with infections quickly spreading from Madras to other cities. Some critics said that quarantine measures and controls had been defective. ${ }^{31}$

In his arguments defending the government, the Union health minister portrayed India's geographical proximity with the rest of Asia and its ports as the inevitable cause of contagious diseases spreading from neighbouring countries with whom there was 'constant communication'. ${ }^{32}$ While representatives from the opposition parties quibbled repeatedly on the floor of the Parliament about the sequence of events and government actions once the ship from Singapore had entered an Indian port, they did not focus on questions of anticipating the pandemic and preparedness. Interest mostly revolved around potential vaccines and cures, rather than public health measures and changing health-related behaviours on the ground, demonstrating a growing faith in laboratory medicine. ${ }^{33}$

Within scientific communities, Indian research, influenced by international agendas, also focused on the search for a vaccine. Since 1950, India was part of a network of influenza surveillance based in London founded by the WHO which sought to make the disease a critical concern. ${ }^{34}$ Research on influenza viruses in India had been initiated after an invitation from the WHO to member states to set up regional research laboratories. In collaboration with the World Influenza Centre, the Government of India established an influenza centre at the

\footnotetext{
${ }^{28 ‘}$ Protest Planned', Times of India, 28 August 1958; '15 Die in Calcutta and Industrial Belt Around', Times of India, 23 April 1958.

${ }^{29}$ 'Two People Die on Saturday Due to Influenza', Jugantar Patrika 20, no. 274 (20 June 1957): 1.

${ }^{30}$ The SS Rajula, a steam passenger and cargo ship built in Glasgow, was mainly used for the Madras-NagapattinamPenang-Port Klang-Singapore service, and was known as a reliable, doughty carrier that had carried Indian troops to Singapore in 1940 and had beaten a massive cyclone in 1966: see Gordon Frickers, 'Useful Facts and Excellent Stories about Rajula at Madras', 8 December 2006, https://www.frickers.co.uk/art/blog/2006/12/08/useful-facts-excellent-stories-aboutrajula-at-madras/.

${ }^{31}$ V. P. Nayar, Quilon, in Lok Sabha Debates, 2nd series, vol. 3, 17 July 1957 (New Delhi: Lok Sabha Secretariat, 1957), 3954 (henceforth cited as LSD, with name of speakers and relevant pages).

${ }^{32}$ Ibid.

${ }^{33}$ D. S. Raju, Rajamundhry, in LSD, 3955-6.

${ }^{34}$ Hyde, World Health Organization; Frederick Dunn, 'Pandemic Influenza in 1957: Review of the International Spread of New Asian Strain 1958', Journal of the American Medical Association 116, no. 10 (1958): 1140-8. As noted above, while the 1957-58 influenza pandemic was not virulent and did not cause large-scale deaths in the world, notice of its spread allowed for the preparation of a vaccine in advance, as it reached Europe and North America only by July-August and peaked there in September-October.
} 
Pasteur Institute of Southern India in Coonoor. ${ }^{35}$ Some years later, a virus research centre was also established, with the help of the Rockefeller Foundation's International Health Division. The Indian Council of Medical Research (ICMR) was enthusiastic about the idea, as they particularly wanted Indian staff trained in immunity studies and arbovirus aetiology, following cases of an influenza-like outbreak of Kyasanur forest disease (KFD), an arbovirus infection, in March 1957. ${ }^{36}$ India's first health minister, Rajkumari Amrit Kaur, and C. G. Pandit, a well-known virologist, worked closely with Dr George Strode at the Rockefeller Foundation to set up the influenza facility. ${ }^{37}$ The virus institute was mobilized a few years later, during the 1957-58 influenza pandemic, to produce sufficient vaccines. ${ }^{38}$

India's scientific elites were keen to partner with virus research networks, but these research centres and their leadership differed in their approach from that of Seal. They did not associate influenza and related infectious diseases (such as pneumonia) with the endemic, embodied risks that Seal had vividly evoked. Several city-based surveys of influenza and the social, contextual vulnerabilities to the disease among poorer families or in industrial settlements would come up in political debates or media reports, but mostly in passing.

To many legislators and public figures, WHO-style networks of surveillance gave little comfort or reassurance. Both past lessons and future plans indicated that economic and industrial development was the crucial step to securing India's immediate future through raising the population's standard of living. Lessons from the past, such as the cataclysmic experience of the 1918-20 pandemic in India and the world, had demonstrated that an influenza pandemic could not be underestimated, especially because of the likelihood of a returning, or second, wave. In speeches by legislators and fact-sharing letters from urban newspaper readers, the influenza pandemic of 1918 served as remembrance, recalled as 'history' rather than a personal or cultural memory and trauma. Politicians referred to it through 'objective' references to past records such as those in the Encyclopaedia Britannica, noting how the colonial context had been marked by a dearth of food, clothes, and other resources in India that aggravated influenza's grave impact, leading to the death of 12.5 million Indians. One politician observed, 'We know there are certain conditions in which the epidemic can spread more easily in India. I think the [health] department ought to have been very vigilant about it.' ${ }^{39}$

The development challenges in India to which some legislators referred were a lack of welfare and social security provisions for the vast majority of the population, making them vulnerable to diseases. A letter published in the Times of India summed up the real dangers experienced in earlier influenza pandemics that persisted in 1957:

Having forgotten the lessons of the 1890 epidemic we were caught unawares in the 1918 epidemic which took a catastrophic toll. Those who have witnessed the ferocity and extent of that pandemic know of the ravages from which not even a village or hamlet escaped ... in October 1918, on some days there were more than 800 deaths daily in the city of Bombay

\footnotetext{
${ }^{35}$ The aim was to isolate the virus, to collect epidemiological information from the nearby Nilgiris district, and to correlate the data with the laboratory findings, to establish the identity of the virus responsible for local outbreaks. N. Veeraraghavan, 'Influenza Virus Isolations at the Government of India Influenza Centre, Coonoor, during 1950-60', Bulletin of the World Health Organization 24 (1961): 679-86.

${ }^{36} \mathrm{KFD}$ is a tick-borne encephalitis, and its outbreaks were preceded by deforestation and the interface of scrub between villages in Shimoga and Beltangady. The virus proved highly virulent among black-faced and rhesus monkeys; its main victims were poor, low-caste agricultural workers. Mark Nichter, 'Kyasanur Forest Disease: An Ethnography of a Disease of Development', Medical Anthropology Quarterly 1, no. 4 (December 1987): 406-23.

${ }^{37}$ C. G. Pandit, My World of Preventive Medicine (New Delhi: Leipzig Press, 1982), 244-6. The aim was for the institution to eventually be run fully by Indian scientists led by the Indian Council of Medical Research.

${ }^{38}$ Questions about vaccines to safeguard against influenza (if there was a second wave) and if it became endemic were a concern. But, as debates began to brew about who would get the vaccine first and especially about access to it for all Indian citizens, influenza cases began to drop and faded away.

${ }^{39}$ V. P. Nayar, Quilon, in LSD, 3954.
} 
alone, whose population at that time was only one million. These facts are mentioned to draw pointed attention to the impending catastrophe before it's too late. Poverty, starvation and lack of security and shelter are the fifth columnists of this epidemic. ${ }^{40}$

Despite these references to 1918 , a relatively mild pandemic such as the 1957-58 influenza had different repercussions in terms of virological research and access to vaccines. Some policy-makers and members of the public inquired about medical research and vaccines that could perhaps compensate for lapses in vigilance. ${ }^{41}$ By May 1957, as the pandemic spread across India, it was clear that older mouse-adapted strains of available vaccine might be ineffective, so aetiological strains had been obtained from those isolated in Malaya; by late May, vaccine production had been initiated in India. ${ }^{42}$ The Armed Forces Medical College in Poona was set a target of 100,000 vaccines; soon after, the Pasteur Institute in Coonoor became involved in helping to produce and test the vaccine. Even as these efforts moved at a fast pace, by late July the pandemic's spread in India had inexplicably ebbed and it became impossible to run a fair trial. ${ }^{43}$

Meanwhile, in many cities newspaper reports affirmed a growing panic and collective anxieties about the epidemic that India's political health leadership in Delhi tried to diffuse. The lack of immediate relief or cure certainly shaped responses throughout the country, and the media were accused of spreading panicky reports and carrying 'sensational headlines'.$^{44}$ India's health minister complained in a parliamentary question hour: 'All of us realise it [the influenza] is not a killer by itself, still one gains the impression by reading the papers that India is in the grip of a very mortal epidemic and hundreds of persons are dying. ${ }^{45}$ The concern for health experts was that even, if death rates were low and there was quick recovery, the morbidity and recovery took time - often several weeks.

Sushila Nayar, an ex-health minister (and Union health minister in India from 1962 to 1967), who was close to Nehru, and a physician who had herself recovered from a recent bout of influenza, reported that, in her constituency near the city of Bhopal,

conditions are very bad. There are whole families lying sick and there is nobody to give them even water. Nobody has taken steps to see that there are emergency beds, emergency measures are taken and something is done to take care of the people. This is so in many parts of India to the best of my knowledge and from what I have heard. ${ }^{46}$

This large-scale incapacitation of the population because of influenza implied that it was difficult to keep public services functional, bringing both urban administration and industrial development programmes to a standstill.

The pandemic spread eastwards from Calcutta into the expanding industrial belt and the coalfields of Jharia, where a rapid rise of influenza cases was reported with concern. ${ }^{47}$ In the eastern state of Bihar, it was reported that more than 200,000 people were laid up with severe flu, with thousands of cases in townships located near collieries such as Dhanbad, Sindhri, and Hazaribagh. ${ }^{48}$ In this eastern industrial belt of coal, iron, steel, and manufacturing industries, and in the emerging industrial sector in cities such as Bombay, absenteeism and lowered productivity were reported among

\footnotetext{
${ }^{40}$ B. G. Vad, 'Letter to the Editor', Times of India, 22 May 1957, emphasis added.

${ }^{41}$ V. Pardeshi, 'Letter to the Editor', Times of India, 18 May 1957.

${ }^{42}$ Menon, '1957 Pandemic of Influenza in India'.

${ }^{43}$ Ibid.

${ }^{44}$ Union Health Minister, D. P. Karmarkar, in LSD, 3971-6.

${ }^{45}$ Ibid., 3973.

${ }^{46}$ Dr. Sushila Nayar, in $L S D, 3973$.

${ }^{47}$ Annual Report of the Director General of Health Services, 1958 (Government of India: New Delhi, 1959), 27-9.

${ }^{48}$ 'Bihar in Grip of Severe Flu: 200,000 People Laid up', Times of India, 16 July 1957, 11. The worst-affected districts were Patna, Gaya, Dhanbad, Hazaribagh, Monghyr, Palmau, Bhagalpur, Saran, and Muzaffarpur. Jharia, Sindhri, Katras, and Jamadoba collieries were also affected. In some cities, such as Sindhri, each family had reported a sick person, and cholera wards were filling up and being converted into flu wards in the city of Patna.
} 
workers. Already iron ore production and distribution-related contracts were getting delayed, and the concern was that these were expanding sectors that could be easily derailed.

In fact, a second wave and return of the Asian flu, and its possible impact was feared precisely because the 1918-20 pandemic had affected a youthful, working-age population. The earlier pandemic had devastated the worker population in the collieries, so strong concerns were expressed about worker sickness vis-à-vis industrial productivity. The urgent need to prepare for a second wave, as articulated by many, was due to worries about India's crucial investment in planning and industrial development. Bombay-based writers brought up an anxiety that was often echoed:

Will history repeat itself? This question readily poses itself to those who lived through 1918 and carry memories of the dreadful dimensions of the mortality it caused ... Adults in the age-group from twenty to forty were the main victims, the excess mortality in some places being about four times the average ... Prostration of so large a section of the population today will seriously hinder, if not jeopardize the execution of the Second Plan [India's Second Five Year Plan, which had a strong focus on rapid industrialization]. We have been forewarned; now we must be forearmed ... A repetition of history can be avoided if we avoid the mere formality of the usual warnings to the public without energetic propaganda. ${ }^{49}$

What was clear was that 'energetic propaganda' and references to hygiene, rather than a scrutiny of welfare, characterized political debates; and when we look at local debates in big cities afflicted by the epidemic, we see that collectivist moral values of productivity, sacrifice, and cooperation were evoked. Pandemic crises at the local level evoked distracting norms of development, urbanization, and its regulation, but more fundamental causes of ill health that could be allied to planning and modernization were still not attracting meaningful attention. The risks of poverty, overcrowding, and labour were related and they soon garnered attention in the following years among experts, but mainly in the context of industrial productivity.

\section{Risks to industrial growth}

The challenges posed by influenza to industrial work and operations in Bombay became a growing fear, and absenteeism among the working class caused by sickness was a particular focus of concern..$^{50}$ Experts were interested in how poor working-class families coped with this health crisis; they identified absenteeism as caused simultaneously by influenza and the psychology of work shirking or deliberate avoidance. In a study conducted among workers in the Glaxo factory in Bombay during the influenza pandemic, researchers reported, 'the epidemic ... caused partial paralysis of essential services like the railway, post and telegraphs, drop in production in textile and other industries, and loss of wage to workers'. Citing data on disease incidence, this study noted higher rates of infection among factory workers than administrative or office workers. It was 'difficult' to determine why, but it had something to do with 'closed-in atmosphere in some departments' and exposure to 'more contacts' and the spread of the disease to families and residential neighbourhoods. ${ }^{51}$ The influenza inquiry focused on the factory workforce affected by influenza (about $46 \%$ of the total). Sections of the Glaxo workforce were absent for five days with a number of days and wages lost. 'In every organization

\footnotetext{
${ }^{49}$ Special Correspondent, 'The 1918 Flu Epidemic Holds a Lesson for Us', Times of India, 14 July 1957.

${ }^{50}$ This section draws on S. Patel and J. Masselos, eds., Identities, Politics and Populism, in Bombay and Mumbai: The City in Transition (New Delhi: Oxford University Press, 2003), 3-30; S. Patel and A. Thorner, Bombay: A Metaphor for Modern India (Bombay: Oxford University Press, 1996); Meena Menon and Neera Adarkar, eds., One Hundred Years, One Hundred Voices: The Mill-Workers of Girangaon: An Oral History (Calcutta and New Delhi: Seagull Press, 2004); Nikhil Rao, House, but No Garden: Apartment Living in Bombay's Suburbs, 1898-1964 (Minneapolis: University of Minnesota Press, 2013).

${ }^{51}$ J. C. Patel, E. R. Demello, A. A. Aiyar and E. Wray, 'A Study of June 1957 Influenza Epidemic in an Industrial Organisation in the City of Bombay', Indian Journal of Medical Sciences 11, no. 8 (1957): 610-18. Another study, comparing influenza across cities, was T. B. Patel and V. N. Rao, 'Comparative Study of the Course of Influenza Epidemic in Bombay City, Poona City and Malegaon Town', Indian Journal of Public Health 2 (1958): 114-16.
} 
there are some nervous employees often called "malingerers". It is possible that individuals of this nature took advantage of the epidemic and remained absent for a longer period than average. ${ }^{52}$

An interest in labour absenteeism and production losses in labour studies both in India and outside was not new, but there were long-standing concerns that the Indian worker was less productive and economically viable compared to others. ${ }^{53}$ The Indian Labour Gazette regularly published figures (which it admitted were only partly reliable) on absenteeism, and, initially, labour commissions and reports alleged that Indian workers were averse to accepting factory-related time discipline, limited leisure, and the limitations of working with machines and such. Indian workers were believed to have a lower commitment to their urban, industrial workplace because of a 'village nexus' with their birthplace that made them unwilling to settle down and led to absenteeism. ${ }^{54}$ Other experts argued that the chronic absenteeism in Indian labour was due to low physical stamina, which was traced to nutritional and psychological factors, exceptionally poor housing, overcrowding, and lack of health facilities. ${ }^{55}$

Absenteeism was already a source of concern both in the West and in India. ${ }^{56}$ There were fundamental and recurring anxieties about working-class populations and the need for industrial efficiency. Urban anthropologists and experts in India, Africa, and the West were fixated on 'adaptation' by workers to industrial life. ${ }^{57}$ Epidemic-related hazards challenged this process of adaptation or, rather, they probed and challenged the relationships between various factors (labour, space, supervision, health) in urban spaces. Layered on top of concerns around absenteeism and sickness were connections between population density and influenza cases in the working-age population. A study of 500 influenza cases in the town of Gwalior, for example, found that almost $75 \%$ of the affected population who had caught influenza were between sixteen and thirty years old. ${ }^{58}$

These worries need to be seen in the context of how development and public health were viewed in these years in the Indian nation's narrative of development and progress. An article in the Times of India termed 1958-59 a year of 'trial and hope', when major decisions were taken, calling for big national sacrifices as India attempted to industrialize rapidly, a process that was expected to eventually lead to better living conditions and resources for all citizens. ${ }^{59}$ There were worries about the slackened rate of industrial production even as the Second Five Year Plan (1956-61) tried to propel India in a 'leap forward' in its steel production. Bombay state's health minister summed up these tensions:

\footnotetext{
${ }^{52}$ Patel et al., 'Study of June 1957 Influenza Epidemic', 615.

${ }^{53} \mathrm{Ibid}$.

${ }^{54}$ There were a dense range of studies on absentee workers dating back to late colonial studies in the 1920s, and to Indian Labour Investigation reports in various industries. See Ranjan K. Som, 'Absenteeism in the Bombay Textile Industry', Calcutta Statistical Association Bulletin (1 October 1953): 24-9; V. L. Rao and V. Lakshminarayana, 'Absenteeism in Industry', Indian Journal of Social Work 11, nos. 1-4 (1951): 255-64; Employers’ Federation of India, Absenteeism in Industries in Bombay: A Survey (Bombay: Employers' Federation of India, 1969).

${ }^{55}$ O. A. Ornati, Jobs and Workers in India (Ithaca: Institute of International Industrial and Labor Relations, Cornell University, 1955), 54: 'The poverty of the industrial worker was far worse ... Indian cities lacked distributive facilities, housing, health facilities. An observer in Calcutta noted that when it rains the worker cannot afford to come to work, he must stay home to be able the get water out of his bustee or else it would have washed away on his return.'

${ }^{56}$ Indian and American experts and International Labour Organization-led investigation committees weighed in on this. See A. N. Agarwala, ed., Indian Labour Problems (Allahabad: Kitabistan, 1947); also Dinkar Laxman Kanade, 'Labor Conditions in Bombay, India' (MA diss. University of California, Berkeley, 1922).

${ }^{57}$ Prakash Gyan, 'The Urban Turn', in Sarai Reader: The Cities of Everyday Life, ed. Ravi Vasudevan et al. (Delhi: Centre for Developing Societies, 2002); Prashant Kidambi, The Making of an Indian Metropolis: Colonial Governance and Public Culture in Bombay, 1890-1920 (Aldershot: Ashgate, 2007); Patel and Thorner, Bombay; Menon and Adarkar, eds., One Hundred Years, One Hundred Voices. Labour historians have pointed out that absenteeism was often exaggerated to justify lower wages and could also be viewed as a site of bargaining and of 'everyday protests' by a marginalized working class, especially women workers, even as owners and the state tried to control them.

${ }^{58}$ P. N. Laha and D. R. Bapet, 'The 1957 Influenza Epidemic: A study of 500 cases admitted into the J. A. Group of Hospitals, Gwalior, M. P.', Journal of the Indian Medical Association 31, no. 2 (1958): 53-8.

${ }^{59}$ 'The National Scene: A Year of Trial and Hope', Times of India, 31 December 1958, 6.
} 
In a country like ours which is on the threshold of intensive industrialization leading to rapid urbanization of a large number of our population, [there are] problems of gross overcrowding and shocking slum conditions with all their dire consequences, even as poor environmental conditions in villages and towns, lack of knowledge and insanitary habits have become a fertile ground for breeding disease and illness in the community. ${ }^{60}$

Others echoed these anxieties, stressing the critical importance of safeguarding densely populated cities and showing awareness that the expansion of urban centres would need far greater commitment to an infrastructure of health and other facilities that was at the time woefully absent. ${ }^{61}$ In 1957, in a parliamentary debate on the influenza epidemic, one speaker added that the epidemic had exerted the maximum toll on densely populated areas: 'this is an important factor that we have got to bear in mind, because as we are rapidly industrialising a large number of places the population is likely to get congregated at a few places. ... When we have to combat future epidemics this is a factor which we have got to remember. ${ }^{\prime 2}$ But instead of analysing the fundamental causes of ill health - such as poverty and social security - the focus of political and public rhetoric, in discussions both during the epidemic and thereafter, was on the 'battle' with pathogens or germs. Meanwhile, both epidemiologists and politicians blamed workers for not being able to 'adjust' to the pressures and fast pace of industrial life and the environment, which was seen as causing longterm chronic psychological and social problems.

Crucial members of India's political and health elite were aware of these choices and the possibilities of reform, but the public health crisis was already making leaders focus on individual responsibility, with a distant promise of a wider, more universal commitment to public health. Sushila Nayar, the erstwhile Union health minister, commented on the all-India response to the pandemic, saying that it carried significant lessons for the future. She noted the importance of managing the epidemic when it was occurring rather than preparing vaccine stockpiles for millions of people. ${ }^{63}$ She said that the government had been unable to mobilize the medical profession and that it was also essential to drum up public cooperation and make the people 'partners in managing diseases'. ${ }^{64}$ In a speech in Parliament, she urged:

We can only organise things in this country if we can stimulate enthusiasm, mobilise the good sense of our people, and there is plenty of it I am sure. We have not done that ... It is for us to go and ask the people for their cooperation, to mobilise their goodwill, and to make use of what they can offer us.

She advised that the government should take on board midwives, vaidyas, and hakims to mitigate suffering, and for all of these groups to brought together to offer relief. ${ }^{65}$

These statements implied that, for the public, their own safety would be both in the government's hands and their own, to direct and guide in a resourceful manner. The Indian public, physicians, and health workers needed to acquire traits that were viewed as necessary for India; and Indians needed to stick to state-led planning and goals to achieve modernization projects, but also to reliably turn to their individual and collective goodwill and good sense to ensure cooperation. D. P. Karmarkar, the health minister in Nehru's cabinet who defended the central

\footnotetext{
${ }^{60}$ T. B. Patel, President, Bombay State Branch of the Indian Public Health Association, Welcome Address, Indian Journal of Public Health 4 (1960): 3.

${ }^{61}$ V. P. Nayar, Quilon, in LSD, 3958.

${ }^{62}$ Ibid.

${ }^{63}$ Particularly when the vaccine was going to give immunity for very little time, and the epidemic was not of a severe nature. Dr Sushila Nayar, in LSD, 3964.

${ }^{64}$ Ibid.

${ }^{65}$ Ibid. Nayar's reference to 'indigenous' practitioners in these debates was a rare voice among a medical elite, and can be traced to her long-standing links to village health through M. K. Gandhi's influence and campaigns.
} 
government's response to the pandemic in Parliament, had a different perspective from many members of the opposition. But even he was aligned with the open-ended notion that pandemic responses and perceived risks need not degenerate into panic, and instead could be constructively directed towards the 'co-operation of the people' as such cooperation was 'precious' ${ }^{66} \mathrm{He}$ also paid 'tribute to the people in general because it is the people in general that always shape the things that are to come. There has been no sense of panic, and I am quite sure if a second wave comes ... the people in the country will be mentally prepared to combat it, to brave it and get through. ${ }^{67}$

Both Nayar's and Karmarkar's comments were about a cooperative citizenry and supportive public that existed only in rhetoric at the time of the influenza epidemic. Efforts to secure cooperation and, in turn, to support the people's health and social security through state schemes and insurance were minimal. As senior members of Nehru's cabinet at different points, Nayar and Karmarkar were closely involved in preparing and planning national health budgets in close coordination with the Planning Commission of India. After the pandemic, there was a focus on 'preventive services that were aimed at controlling the spread of communicable diseases and prevention of epidemics' ${ }^{68}$ By 1962, it was argued that the containment and eradication of infectious disease outbreaks were on the brink of success, with malaria also on the verge of eradication. ${ }^{69}$ The Second Five Year Plan had put the highest priority and two-thirds of the entire budget on the development of industry, transport, irrigation, and power, and the Planning Commission's Health Panel that met in 1955 had been told that 'social services will have to take a back seat until the economy of the nation had been adequately strengthened'. ${ }^{70}$ In 1962, Nayar (who had by then succeeded Karmarkar as health minister) admitted that the Third Five Year Plan had 'elicited feelings of disappointment' at the modest allocation for health; it lacked a 'liberal treatment' and states had to slash their public health schemes to accommodate national disease programmes. ${ }^{71}$ She also noted that the problems of health seemed to have been viewed in isolation and not as part of a wider, social security programme. This was interesting because these years saw a growing understanding that health and its social and economic context were crucial. Health experts linked this to social services and welfare provisions, and knew that it was vital to ensure implementation of preventive health measures. In 1961, Rajkumari Amrit Kaur, who spoke more frankly after stepping down from Nehru's cabinet, noted that Indians were:

apt to judge national prosperity purely on an economic basis ... Little do such ignorant folk realise that intelligent co-operation can only come from those who are educated enough to understand and likewise that the skilled workman will always yield better results. And yet again that no worthwhile output can be expected from the undernourished or poorly housed, and no education can be imparted to the sick child. ${ }^{72}$

\footnotetext{
${ }^{66}$ D. P. Karmarkar, in $L S D, 3984$.

${ }^{67}$ Ibid.

${ }^{68}$ 'Welcome Speech by P. K. Savant, Minister for Public Health, Government of Maharashtra', in Summary Proceedings of the Tenth Meeting of the Central Council of Health, Held at Mahabaleshwar (Maharashtra) on 17, 18 and 19 October 1962 (New Delhi: Government of India, [1962-3]), 8.

${ }^{69} \mathrm{Ibid}$. This meeting was chaired by Dr Sushila Nayar, Union health minister, and attended by heads of the Directorate General of Health Services, Health Division, and other ministries.

${ }^{70}$ Report of the first meeting of the panel on health programmes, October 1955, Planning Commission, Government of India, 23, cited in Jean Joyce, Health in New India: The Story of Free India's War Against Disease, 1947-1961 (Ford Foundation, 1961).

${ }^{71}$ Opening Address by Dr Sushila Nayar, in Summary Proceedings of the Tenth Meeting, 10-11.

${ }^{72}$ Rajkumari Amrit Kaur was India's first Health Minister, and was elected President of the World Health Assembly (1950). Rajkumari Amrit Kaur, The Concept of Social Service: Its Relation to World Needs and Problems, An Address given by Rajkumari Amrit Kaur, Formerly Minister of Health in India, at the Tenth International Conference of Social Work, Rome, 1961 (London: National Council of Social Service, 1961), 22, emphasis added. See also Medha Kudaisya, 'Developmental Planning in "Retreat": Ideas, Instruments, and Contestations of Planning in India, 1967-1971', Modern Asian Studies 49, no. 3 (2015): 714-15.
} 
Nayar and Amrit Kaur were influential health ministers, charismatic and with long-standing connections with leaders in India's Planning Commission and the Indian National Congress's political leadership. Amrit Kaur's interpretation of 'intelligent' citizen cooperation assumed a degree of participation and volition on the part of labour or other classes in deciding the direction and priorities of the modernization plans, but this participation was never a part of this elite and expertguided modernization project. She was not responding specifically to a pandemic and its crisis, but speaking about creating a citizenry that was responsive because it was educated and found its health and welfare needs met. The middle classes clearly had some incentives to cooperate with this vision of education and health, and many others would join their ranks if they were offered mobility through better health and housing, but these ideas were not given concrete pathways in urban health.

Connecting the lines in these speeches and ideas, it becomes clear that epidemic crises such as the influenza pandemic and their aftermath brought up more intense debates about disease risks among poorer and deprived populations, but there was also a tendency to deflect and view the crisis beyond health, in terms of its stakes in the industrial sector. A government health committee headed by Dr A. L. Mudaliar and consisting of eminent health experts did highlight lessons from the influenza pandemic of $1957-58 .{ }^{73}$ However, their perspective and recommendations focused on influenza as a 'global problem'. They raised ideas about deepening international ties with the WHO's Influenza Centre and suggested bolstering quarantine plans during outbreaks, but their main emphasis was on promoting medical research and exploring vaccine manufacture in India. These discussions turned attention away from visible, endemic disparities and the sharp differences in the degrees of suffering, health access, and precarities that had been experienced by the working classes, migrants, and the middle classes in cities. ${ }^{74}$

\section{From productivity to responsibility: a cooperative, urban citizenry}

During the months of the influenza epidemic, in cities such as Bombay, public health authorities stepped back from assuming deeper responsibilities. The focus was on the state taking on the roles of policing and vigilance at the margins: being responsible for inspections and closures of theatres and schools in the locality, and guiding people to overcrowded hospitals. In the realm of hygiene and prevention, the focus was on self-help and encouraging social habits that prevented the spread of influenza. Legislators and health experts stressed the need to communicate with the wider public urgently about hygiene; in effect, however, the 'people' - that is an urban, literate audience consisting of middle classes - were expected to read and follow government instructions posted in newspapers or other pamphlets.

The government of Bombay issued a statement advising people on measures they should take to prevent the spread of influenza. ${ }^{75}$ The urban public was told to 'avoid fatigue and exposure to extremes of heat and cold', and to 'avoid visiting or coming into contact with persons suffering from "flu". They were asked to avoid places of amusement or any large meetings. The extensive population of informal workers, migrants, homeless, and industrial and mill labour, who had no recourse to rest and recovery nor to distanced surroundings or quarantine of family members, were forgotten. The government also advised the use of 'paper handkerchiefs' that 'should be immediately burned' if persons had to spit or to sneeze, and they advised consulting a physician

\footnotetext{
${ }^{73}$ Government of India, Report of Health Survey and Planning Committee (New Delhi: Ministry of Health, 1964), 295-6, 365,382 . This committee was set up to assess health sector performance.

${ }^{74}$ Ibid., 295-6. See also Rhyddhi Chakraborty and Chhanda Chakraborti, 'Pandemic Influenza Planning and Response in India, 1949-2009', Eubios Journal of Asian and International Bioethics 25, no. 1 (2015): 7-13; B. L. Rao, 'Epidemiology and Control of Influenza', National Medical Journal of India 16, no. 3 (2003): 143-9.

${ }^{75}$ 'Preventive Steps Suggested: Government Advice to People’, Times of India, 4 June 1957.
} 
if there were signs of fever. These measures assumed that members of the public had a stockpile of paper handkerchiefs at home to burn (in a market and consumption culture where access to and usage of these was limited), and were able to consult a physician and pay for their fees.

The message itself, stilted and limiting as it was, did serve one important purpose: it distanced the government from direct responsibility for all but acute medical relief. It told people to be responsible and empowered through their everyday actions and public health and hygienic observances, to stem the pandemic. In Madras, patients were directed to the city's infectious disease hospitals, which were already a site of stigma and overcrowding. The City's director of medical services also issued a list of dos and don't's to fumigate homes, including instructions to 'avoid public places, and fatigue, ...Gargle with a mild salt solution', and 'Don't get panicky'. The public were told that the outbreak was 'mild and ordinary' and would resolve itself with simple medication. ${ }^{76}$ The messages assumed that their audience had access to stable housing, a choice of leisure activities, ability to avoid work and crowded places, a degree of self-diagnosis in terms of testing for fever and symptoms, and access to warmth and good ventilation.

The tone and content of this messaging was not surprising. Other public health advisory notices used similar, paternalistic tones aimed at coaching citizens and recipients about the Indian state's health and development programmes and the fundamentals of hygiene. These messages focused on disease vectors such as flies, on asking the public to live in clean, mopped surroundings and to use mesh netting on their windows, and on sharing other instructions that excluded all but well-off, propertied communities in urban and rural areas. ${ }^{77}$ The notices during the influenza pandemic, however, were not simply about general hygiene. They instructed the public on travel, social interactions, and citizen sensibilities, such as resilience. They also addressed the crisis caused by the 'Asian' influenza outbreaks that affected most Indian towns and cities, and tried to quell panic and to build a climate of self-help and sufficiency rather than offering better-coordinated government services.

The Indian state increasingly made out that controlling influenza and surviving these disease onslaughts through hygienic practices was within the immediate reach of individual agency and initiative. There was, I argue, a more empowered, individual-centred, and self-reliant public health portrayed here as a priority, at a time of pandemic. Even as the state spearheaded specific national disease programmes, there were two distinct levels of health-related risks involved: those that were possible to contain by urging citizens to fight and mobilize during limited disease crises; and those, such as smallpox, malaria, and tuberculosis, that a deterrent Indian developmental state would try to contain. What the interactions and exchanges in this period demonstrate is that, even though the Indian state was still speaking about social protection and welfare relating to health, there was a neoliberal sensibility that stressed the individualism and enterprise of cooperative and selfreliant citizens responsible for their own health. ${ }^{78}$ For the industrial labour force, health risks were endemic, as welfare benefits for the majority and risk coverage offered by employers were low; at the same time wages and living standards were poor. A news article that quoted the 1957-58 annual report on the Employee State Insurance Corporation (ESIC) said that the ESIC admitted that the previous year's influenza epidemic had created a 'crisis', had subjected employee health insurance to an 'exacting test', and had 'dislocated' its working. The writer observed, that if a medical service failed to function in a crisis, 'its efficiency must surely be questioned', and that the

\footnotetext{
${ }^{76}$ 'Doctors Fear Spread of Flu Epidemic to Madras', Times of India, 25 May 1957.

${ }^{77}$ Instructions on 'Anti-Fly Week' had 'admirable bits of advice', such as wiping children's runny noses and wiping floors with Lysol and Phenyle, that were termed by one writer as not practicable for the present economic condition of the people. See 'Sidetrack' column, Yojana 6, no. 14 (1962).

${ }^{78}$ On neoliberalism and health reforms in India in the 1990s, see Imrana Qadeer, Kasturi Sen, and K. R. Nayar, eds., Public Health and the Poverty of Reforms: The South Asian Predicament (New Delhi: Sage Publications, 2001).
} 
previous two years had shown a decrease in the numbers of workers insured under the ESIC scheme. In 1957-58, only half of the insurable population of more than two million workers had been covered. ${ }^{79}$ Meanwhile, for the urban middle classes, these attitudes to epidemic outbreaks of influenza had a different lesson, reinforcing to them the need to rely on their own enterprise in efforts to control and regulate residential neighbourhoods, gauge the medical market, and coordinate with and help each other.

During the influenza epidemic, even as the municipal government in Bombay stressed that it was for citizens to build a 'civic conscience' to contain the risks (rather than for the government to step up to do so), they implicitly drew new, socially exclusionary boundaries between workingclass and middle-class neighbourhoods, especially at a time when the textile mills and industrial areas were becoming contested sites of trade union activity. In December 1958, a few months after the epidemic threat had diminished, the Governor of Bombay suggested that the city's municipality should construct shelters for pavement dwellers, distinguishing the spaces occupied by the urban poor. He noted that this would make it possible to 'keep the city clean and arrest epidemics', implying that these shifting, migratory populations of pavement dwellers were not simply an affront to city planning, but also a threatening presence that could provide a breeding ground for epidemic outbreaks. ${ }^{80}$

The Citizen's Civic Welfare League in the middle class locality of Matunga responded to these calls, organizing a civic conference in an effort to rouse civic consciousness among people, especially to improve their sense of hygiene and the avoidance of bad practice 'such as spitting and throwing refuse on public thoroughfares'. The population of the city had increased but not the resources of the corporation and, therefore, 'The greatest need in municipal life at the present crucial period in history of our country is not a mere extension of the obligatory duties and optional powers, but a reconstruction of the whole conception of civic pride, civic duty and civic glory. ${ }^{\prime 21}$ This would require the administrative officials and municipal councillors to work with citizens, and this speech referred pointedly to growing middle-class-led politics of neighbourhood and area welfare associations and their efforts to shape urban citizenship. ${ }^{82}$ It was a social world where the understanding of health-related preventive measures and civic reform implied engaging with the urban middle classes and philanthropies as in colonial Bombay, but these middle classes were now assuming new visions to shape their spaces and surroundings. However, their visions excluded the city's working classes, whose 'productivity' and labour were deemed vital, but who were seen in times of a health crisis as sources and spreaders of potential infections.

There were other sites of engagement and contestation as urban middle-class populations grappled with flu risks and morbidities. The absence of state regulation in a burgeoning and uncontrolled urban market for flu remedies was increasingly noted in local news reports and even in contemporary films. Historians have pointed out that the design of newspapers like the Bombay Chronicle was altered by a growth in advertisements aimed at an Indian rather than a European consumer, with medicines and soaps becoming very competitive markets for pharmacies and businesses in the interwar years. ${ }^{83}$ During the 1957-58 pandemic (and also later, during the

\footnotetext{
${ }^{79}$ This was attributed to a lack of political will, 'red tapism', and a paucity of medical and health services accessible to urban workers. 'A Critical Year?', Times of India, 26 September 1958, 6.

${ }^{80 ‘}$ Measures to Keep City Clean: Governor's Call', Times of India, 1 December 1958, 3.

${ }^{81}$ Ibid.

${ }^{82}$ Patel and Thorner, Bombay; Rao, House, but No Garden. See also Partha Chatterjee, The Politics of the Governed: Reflections on Popular Politics in Most of the World (New York: Columbia University Press, 2004); Marie-Hélène Zerah, 'Middle Class Neighbourhood Associations as Political Players in Mumbai', Economic and Political Weekly 42, no. 7 (2007): 61-8; K. Coelho and T. Venkat, 'The Politics of Civil Society: Neighbourhood Associationism in Chennai', Economic and Political Weekly 44, no. 26-7 (2009): 358-67.

${ }^{83}$ Douglas E. Haynes, Abigail McGowan, Tirthankar Roy, and Haruka Yanagisawa, eds., Towards a History of Consumption in South Asia (New Delhi: Oxford University Press, 2010), 1-25.
} 
1968-69 influenza pandemic), Indian newspapers were flooded with competing claims regarding therapies and cures. The market was so overwhelmed by these advertisements over print and radio that it came to the attention of legislators in the Indian Parliament, who asked for these claims to be verified, especially as many pharmacies were offering untested flu 'cures' ${ }^{84}$

The flu also found its way into films. ${ }^{85}$ Madras city was badly affected by influenza cases in both visitations of the pandemic. During the 1957-58 outbreak, the Tamil movie Bhaga Pirivinai (1959), featuring a well-known comedian, M. R. Radha, had a popular satirical scene that illustrated how cynical profiteers were producing mostly ineffective and untested flu medicines to meet the demands of a vulnerable public seeking relief. Radha played the role of a friendly person who meets an executive of a pharmaceutical company and exchanges notes about the devastation caused by the flu in Madras. They discuss the mysterious origins of the flu, the immediate devastation it causes in the city, and the opportunities it presents for unscrupulous 'big business'. What becomes clear to the audience in this parody is that the real and invisible risks in this medical market are the epidemiological risks of the flu and also an unchecked, capitalistic market enterprise and its assaults on the consumer. The message in these exchanges was clear: that the 'common' or ordinary public of cinemagoers had to be both vigilant consumers and citizens, and needed to cultivate an awareness of these threats in the local arena.

Another striking aspect during the 1957-58 health crisis was the remarkable silence in the news reports and discussions among experts about how influenza had affected rural areas and village populations. The epidemic was seen primarily as a threat to urban populations, and the voices we hear in newspapers and journals based in large cities such as Bombay, Madras, and Calcutta capture a specific but somewhat narrow set of concerns and rhetoric that underscored modernization and industrial goals. My ongoing work on health and medical periodicals published by indigenous practitioners, local pharmacists from small north Indian towns and cities, attests to a distinct, divergent register of concerns. ${ }^{86}$ They alleged that they were being neglected by an elite consisting of Western-educated experts (for example, Rajkumari Amrit Kaur's 'stepmotherly' bias towards Ayurvedic medicine and her investment as health minister only in 'Western' therapeutics, research, and planning goals that prioritized the needs of big cities and a medical elite). They evoked untapped resources in terms of health care and services that could be trained and mobilized from the 'bottom up' rather than 'top down'. Instead, national planning agencies looked abroad for sanction and validation rather than from within to tackle India's health crises. ${ }^{87}$

In 1957-58, influenza was portrayed primarily as a disease of 'density' and associated with the urban proliferation of people and new industries, while the countryside was viewed as having escaped its ravages. Cities and countryside with smaller towns and villages were conveniently made out to be separate spheres, linked for economic reasons but distinct in epidemiological profiles. It is more likely, as discussions of disease and cause of death reporting in public health journals demonstrated, that influenza reporting in the countryside was simply not being done: cases of plague, smallpox, and malaria in the countryside were recognized and reported as notifiable diseases but deaths caused by fevers and congestion were reported without specific references to influenza. Epidemiologists who conducted surveys on influenza incidence in rural areas such as Singur near Calcutta in 1957-58 observed that more than half of the families sampled there had suffered from

\footnotetext{
${ }^{84}$ V. P. Nayar, Quilon, in LSD, 3975-7. The debate also focused on whether these 'wonder cure' advertisements violated the Drugs and Magic Remedies Act 1954.

${ }^{85} \mathrm{I}$ am grateful to Prof. V.R. Muraleedharan at IIT Madras for discussions on old Tamil films, and help in accessing Tamil periodical archives in Chennai.

${ }^{86} \mathrm{My}$ current research focuses on Hindi journals such as Vigyan (Science), Arogya (Health), and others that raised these arguments in articles and editorials the 1950s. See Shri Kumar Yogi, 'Hamare Rashtra Swasthya Ki Samasya' ('Our National Health Challenges'), Saraswati, 16 January 1950, 16-23.

${ }^{87}$ Editorial, 'Rajkumari Amrit Kaur and Health Services', Journal of Ayurveda, 4 (1952): 270-6; also in later issues.
} 
influenza over the course of eight or nine weeks, but it was their ties with Calcutta's industrial areas and links to markets that were understood as having spread the epidemic. ${ }^{88}$

\section{From challenging development to the challenges of development}

On 9 September 1968, the influenza virus again arrived on Indian shores, once more sailing aboard the SS Rajula. ${ }^{89}$ If history seemed to be repeating itself, the Indian press missed evoking memories and similarities of a decade earlier. There was concern about outbreaks, but this return was no surprise and influenza had become a predictable menace. India was merely a port of visitation on the path to a pandemic that had spread across the world; scientists paid barely any attention to the mode of contagion and transfer. The Indian press reported that the World Influenza Centre in London had traced this outbreak to the revival of the Asian flu of 1957, and that the new pandemic, called Hong Kong A2 influenza, had now spread from there to Madras, to Cape Town, and to Canada, and also eastwards to Manila, Tokyo, and the western coast of the US. ${ }^{90}$

This second influenza pandemic allows us to see the emergence of a sense of collective risk, as experts discussed the complex fallout of science and modernization rather than its unfiltered benefits, and acknowledged that international goals, targets, and partnerships had complicated implications. Development plans - and the leaps of faith and planning associated with them - were as much of a social risk as were the linked spread of pathogens and pandemics. Attitudes towards public health crises and development programmes were also beginning to shift in significant ways. By the mid 1960s, Indian public health experts were moving away from seeing epidemics like influenza as threatening industrial modernization projects, stymying labour productivity and urban growth. A decade after the last pandemic, public health experts, economic and labour reports, and journals and national newspapers no longer dwelt urgently on these aspects of infectious disease outbreaks. In terms of challenges to productivity, chronic diseases and occupational exposures were gaining more interest through the 1960s, pushing aside the focus on the social and moral hazards of absenteeism and 'truancy' that were a continuum from colonial concerns about labour discipline (which had assumed a new impetus in the 1950s with the growing urban migration of workers and the instability of urban growth). Mill and factory owners, as well as state research funds and agencies, now focused on other bodily hazards, such as the health hazards of radiant heat, thermal stress, and work output; state research support funded these concerns and those of nutrition, diet, and social-psychological research on group morale. ${ }^{91}$ All of these were seen as having a more fundamental effect on labour participation and production efficiency. ${ }^{92}$

In the years during and after the 1957-58 influenza pandemic there was also a growing network of scientists who were researching influenza in India; the Mudaliar report and leading Indian

\footnotetext{
${ }^{88}$ In Singur, the attack rate of influenza had been 234.2 per thousand and in Calcutta it was 598.4 per thousand. Begumpore was the centre of a handloom industry, and the daily contact with Calcutta, Howrah, and other industrial neighbourhoods for marketing produce there implied that this population suffered more, though fatalities were low. M. Bhattacharji, P. C. Sen, R. N. Basu, and B. Sanyal, 'Epidemiological Observations on the Influenza in the Rural Areas of Singur, West Bengal, during June-August', Indian Journal of Medical Research 47, no. 1 (1959): 113-18.

${ }^{89}$ Scientists reporting from the Pasteur Institute at Coonoor noted that preliminary tests indicated that the virus had arrived with a consignment of sheep that had been shipped to Madras aboard the Rajula from Singapore (though there were contradictory accounts). 'Indian News in Brief, Times of India, 9 October 1968, 11.

${ }^{90}$ 'Flu Stalks Bombay', Times of India, 24 September 1968, 7; 'Current Topics: Economics of the Flu', Times of India, 18 October 1968, 10.

${ }^{91}$ C.G. Pandit and Someswara Rao, Fifty Years of Progress: Indian Research Fund Association and Indian Council of Medical Research (New Delhi: Indian Council of Medical Research, 1962), 77-9; Opening Address, Proceedings of the Seminar on Pollution and Human Environment: CoST Working Group on Human Environment, 26-27 August 1970 (Bombay: Bhabha Research Center, 1970), 10-12.

${ }^{92}$ There was also finally a focus on trying to understand rather than deny the existence of lead poisoning, chest infections relating to cotton dust and bagassosis, and new diseases such as occupational dermatitis and occupational deafness, which were hitherto not known to exist in the country.
} 
scientists had further endorsed this research and urged the development of vaccines at the Indian Virology Centre in Pune. Based on the virus/influenza-centred research set up a decade earlier, Indian scientists, especially microbiologists, also recognized that both poverty and underdevelopment exposed poorer, undernourished populations to new pandemics. ${ }^{93}$

The influenza pandemic, and concerns about old and new disease vectors, had spurred Indo-US cooperation on arbovirus and bird migration research. But efforts to collaborate between the Virus Center Unit in Poona with researchers on the genetic control of mosquitoes programmes (relating to dengue outbreaks) with US defence agencies and with researchers at Johns Hopkins University began to be viewed by Indian politicians as having taken a 'sinister turn'. ${ }^{94}$ The Indian government started an inquiry on the risks of genetic engineering, involving the collection of virological and epidemiological materials in India on antigenic stability and mutations among pathogens, and this research was suspected of posing a risk of biological and chemical warfare against India. ${ }^{95}$ Increasingly, it was clear that the challenges in development planning and some reversals in disease eradication (such as in the malaria programme) spelled out that disease control projects could pose unexpected risks and uncertainties.

Nehru's letter to his daughter had captured the compelling dilemmas of science and the fact that, while modernization and development could limit disease threats, they might also proliferate new risks. The postcolonial predicament in India brought an awareness and public admission by the state that public health crises needed citizens to act, cooperate, and share risks and vulnerabilities, even though a majority of them had reaped few, if any, benefits from these development projects. I have argued that understanding this process is critical for allowing us to situate the deep, rhetorical roots of 'neoliberal' approaches. We see the activities and responses of an Indian state that invoked collective sensibilities of individual responsibility and self-help during a health crisis, long before globalized, neoliberal doctrines were diffused and unfolded in the 1990s. Finally, as the COVID-19 pandemic and the tragic crisis of migrant workers demonstrated recently in India - as workers trekked back thousands of miles on foot to their villages after their factories shut down - the uncertainties and devastating pain of pandemic disease and its endemic risks continue to be borne in unequal and disparate ways in Indian society. ${ }^{96}$

Kavita Sivaramakrishnan is Associate Professor, Sociomedical Sciences at the Mailman School of Public Health, Columbia University. She is a historian of public health and science in South Asia; and is deeply interested in the politics of global health. Published works include Old Potions, New Bottles (2006) and As the World Ages: The Making of a Demographic Crisis (2018). Her current work focuses on histories of epidemics, hygiene, and the public; the politics of experts, risk, and expert knowledge; and loneliness among older populations. She is also co-leading a project on COVID-19 and its social networks and politics in New York city supported by the National Science Foundation.

\footnotetext{
${ }^{93}$ Government of India, Report of Health Survey and Planning Committee, 295-6, 365, 382 (senior Indian scientists spoke at this meeting); Freitas and Fernandes, eds., Global Impacts of Applied Microbiology.

${ }^{94}$ Kendal Powell and K. S. Jayaraman, 'Mosquito Researchers Deny Secretly Plotting Biowarfare Test', Nature, 419 (31 October 2002): 867.

${ }^{95}$ Public Accounts Committee, 'Foreign Participation or Collaboration in Research Projects in India', in 200th Report, Public Accounts Committee, Lok Sabha, Ministry of Health and Family Planning (March 1976), 1-6. See discussion of this biological warfare test using mosquitoes in 1965 in Powell and Jayaraman, 'Mosquito Researchers'.

${ }^{96} J o a n n$, Slater and Niha Masih, 'In India, the World's Biggest Lockdown Has Forced Migrants to Walk Hundreds of Miles Home', Washington Post, 27 March 2020, https://www.washingtonpost.com/world/asia_pacific/india-coronavirus-lockdownmigrant-workers/2020/03/27/a62df166-6f7d-11ea-a156-0048b62cdb51_story.html.
}

Cite this article: Sivaramakrishnan K. 2020. Endemic risks: influenza pandemics, public health, and making self-reliant Indian citizens. Journal of Global History 15: 459-477, doi:10.1017/S1740022820000340 